\title{
Creating a knowledge-based forest sector
}

\author{
by Clark S. Binkley
}

Traditionally an industry based on plentiful natural resources, the forest sector in British Columbia must be transformed to include a far higher amount of technology if its prosperity is to be sustained. Only by embodying a larger technological component in its products and processes can the forest sector offset the economic decline usually associated with the transition from old-growth to secondary, managed forests. Research will also increase the contribution the forests themselves can make to our economic and environmental well-being. Because of its position as a large producer of forest products, effective research strategies for British Columbia (and probably for Canada more broadly) will differ substantially from those pursued by major consuming nations such as the United States or Japan.

Because of the large land areas involved and the large standing stock of timber, the forest sector is commonly regarded as being based on natural resources. While the land, water, climate and vegetation itself are indeed critical to the health of the sector, knowledge has become the more limiting factor. Now is the time to reconceptualize the sector and transform it into a knowledge-based one.

The transformation is

- an economic necessity to offset powerful economic forces which, if not managed, will force the sector into an inevitable decline

- a political necessity to create a stable public policy context in which the industry can operate

- a social necessity to produce more goods and services from a land base shrinking under the weight of population expansion and increased incomes.

Most calls for expanded research rely on the economic benefits that accrue from this activity (Evenson et al 1979, Seldon and Hyde 1991, Hyde, Newman and Seldon 1989). While these arguments are powerful ones, this paper focuses on the more narrow interests of the sector itself. It begins with a brief review of the current expenditures on research and development. The next two sections discuss the economic and political dimensions of the problem. The penultimate section describes some elements of the needed research strategy, and frames some of the important questions that remain to be resolved. The conclusion argues that an expanded, strategically targeted research program is prerequisite to the economic health of the sector - the firms involved, their employees and stockholders, the vast fraction of the economy in British Columbia that depends directly or indirectly on the sector and the societal services funded from its surpluses.

\section{The Current Situation}

Comparing the expenditures on forestry research in British Columbia, the United States and Sweden provides some insights

Faculty of Forestry, 270-2357 Main Mall, MacMillan Building, University of British Columbia, Vancouver, BC, Canada V6T 1 Z4.
Le secteur forestier de la Colombie-Britannique, une industrie reposant traditionnellement sur des ressources naturelles abondantes, doit être transformé pour inclure une proportion beaucoup plus grande de technologie si nous voulons maintenir sa prospérité. Ce n'est qu'en incorporant une composante technologique plus importante dans ses produits et ses procédés que le secteur forestier pourra compenser pour le dangereux déclin économique associé à la transition des vieilles forêts aux forêts aménagées de seconde venue. La recherche accroîtra également la contribution que les forêts peuvent apporter par elles-mêmes à notre mieux-être économique et environnemental. A cause de sa position en tant qu'important producteur de produits forestiers, les stratégies de recherche efficaces pour la ColombieBritannique (et probablement pour le Canada dans un sens plus large) différeront substantiellement de celles suivies par les plus importants pays consommateurs tels les États-Unis ou le Japon.

into the problem. Binkley and Watts (1992) give a more complete assessment of the forestry research situation in British Columbia. Sweden possesses a mature forest sector operating on roughly half the forest land as British Columbia and, as a consequence of natural factors and exclusive reliance on secondary forests, a slightly lower level of harvest. As in British Columbia, the forest sector looms large in Sweden's economy. The United States is both the major market and the major competitor for forest products from British Columbia. Despite its vast area (forests comprise about one third the total land base of the United States), the forest sector accounts for less than $5 \%$ of the total economic activity in the United States. In contrast both to British Columbia where virtually all of the harvest comes from primary forests, and to Sweden where all of the harvest comes from secondary forests, the United States is in the last stages of the transition from a reliance on oldgrowth to dependence on second growth.

Table 1 shows the forestry research expenditures in the three jurisdications as a percentage of gross sales of their forest sectors. By this measure, British Columbia spends nearly an order of magnitude less on forestry research than does Sweden. Because British Columbia's forest sector is relatively young compared to that in Sweden, the returns to research arguably may be higher here than there.

What do these figures mean for British Columbia in absolute terms? In 1989 we spent about \$34 million on forestry research in the province, of which $\$ 13.9$ million or $40.6 \%$ came from federal sources (Forestry Canada, NSERC, and the federal share of the Forestry Resource Development Agreement). Using the Swedish ratio of research expenditures to gross sales implies about a seven-fold increase, to \$237 million/year.

Why should we spend this amount? If we should, how should we target this research? What are the impediments to mounting a forestry research program of this magnitude?

\section{The Economic Necessity}

Avoiding both relative and absolute economic decline of the forest sector requires embodying a greater amount of 
Table 1. Expenditures of forestry research as a fraction of gross forest products sales (1989)

$\begin{array}{ll}\text { Sweden } & 1.75 \% \\ \text { United States } & 1.2 \% \\ \text { British Columbia } & 0.26 \%\end{array}$

Source: Science Council of British Columbia (1989).

knowledge in each unit of output. This can only be accomplished by developing and adopting new technologies. To explain the economic necessity of research consider the long sweep of history. In the long run, forest sector development involves the transition between old- and second-growth forests. Hold labour supply and product demand constant to focus clearly on the issue at hand, with full knowledge that the real world contains a much richer fabric of complications.

With these simplified but instructive assumptions, consider a country embedded in a world forest sector. Imagine that this country discovers an old-growth timber resource, large enough so that its development is significant in world markets. In the absence of policy intervention, how does the forest sector develop?

The first part of this story is the comparatively old and well known saga of the adjustment of the timber stock over time (Lyon 1981, Sedjo and Lyon 1983, Sedjo and Lyon 1990, Sedjo 1990). The second part links the adjustment of the stock to the dynamics of the forest sector, the macroeconomy and the environment more broadly (Vincent and Binkley 1991, 1992, Vincent and Newmark 1992).

\section{Dynamic Adjustment of the Timber Stock}

In the early stages of development, net growth of the forest is nil: photosynthesis balances the death of plant tissues and entire trees. Because growth is nil, any harvest at all exceeds the growth of the forest, and the timber inventory declines.

As the inventory of old growth declines, timber becomes more scarce. Prices (or implicit valuations in cases where market prices are not recorded) rise until the production of second growth becomes economic. In the absence of subsidies, high-cost old growth will remain unharvested and will become economic wilderness. We see this today in remote locations in British Columbia and elsewhere in the world. Because timber prices have risen, other countries can compete in world markets, either by exploiting their own oldgrowth resources (for example the Philippines, Indonesia and Malaysia) or by developing plantations (for example New Zealand, Chile and South Africa).

In broad lines, this story is consistent with the development of the forest sector in the United States (Clawson 1979, Sedjo 1990). Harvest exceeded growth until the middle of this century when the timber inventory stabilized and began to increase. Timber prices rose at a real rate of about $4.6 \%$ year between 1910 and World War II, and 3.1\% from that period to the mid-1980's (Binkley and Vincent 1988).

What do these adjustments of the timber stock imply for such important macroeconomic concerns as capital, labour, governmental revenues, environmental values and the relative economic importance of the forest sector?

\section{Capital and Labour}

In economic terms, harvesting timber transforms ecological capital into economic capital. The reduction in timber stocks therefore increases the supply of fungible capital in the economy. The price of capital declines relative to the price of labour. Because timber prices are rising, the price of capital falls even further relative to the price of timber.

The technology used to process timber logically adapts to the changes in the prices of inputs: firms substitute capital for timber. Because of the nature of equipment used in the forest sector, capital-timber substitution typically reduces specific labour utilization as well. Reduction in the cost of capital relative to wage rates provides a further incentive to reduce labour usage. The resulting increase in efficiency reduces the employment per unit of output, and possibly the total employment in the sector as well. For example, between 1961 and 1989 in British Columbia, specific labour utilization in the forest sector fell by a factor of two. In this same period, the overall harvest rose by a factor of nearly three (Nixon 1991).

Increases in timber prices drive up product prices (although at a lower rate). This encourages substitution away from conventional wood-based products. So, for example, the consumption of softwood lumber in the United States has remained roughly constant since 1900 at $40-50$ billion board feet annually despite a seven-fold increase in economic activity and more than a doubling in population. Per capita consumption has fallen from almost 600 board feet/capita to less than 200 .

\section{Relative Importance of the Forest Sector}

In the autonomous development of the forest sector, the relative economic importance of the forest sector will decline.

The area of forest land decreases as land is converted from forest cover to agriculture, and as harvests occur on land that is outside the extensive margin for economically sustainable timber production. In the United States, the area of productive forest land declined by half between European colonization and the present. In the late 1800's, the rate of deforestation in the United States exceeded the current rate in Latin America by about a factor of about ten.

The share of gross domestic product commanded by the forest sector will fall. Non-forest sector manufacturing will increase in response to the reduction in the cost of capital. Forest sector activity itself may decrease due to the depletion of old growth. In British Columbia, the forest sector's direct share of GDP has fallen from slightly over $15 \%$ in the early 1960 's to about $9 \%$ at present. With "status quo" policies, the annual allowable cut in British Columbia may fall from its current level of about 75 million $\mathrm{m}^{3} /$ year to 46 million $\mathrm{m}^{3} / \mathrm{yr}$ by the year 2000 (B. Devitt, personal communication).

Tax revenues collected from the forest sector may decline. If the government seeks to maintain the total amount of revenue collected from the forest sector, the tax rates per unit of wood will increase. This adjustment is logical when considered in light of the short-run needs to maintain critical governmental services, but will create a self-perpetuating downward spiral of increased costs and loss of international competitiveness in the country's forest sector.

The political importance of the forest sector is apt to decline in parallel with the reduction in relative economic importance. The forest sector will lose control over the economic environment in which decisions by individual firms are made. So, for example, currency exchange-rate policies may be dictated by the forest sector when it is large in the economy, but not when it is small. 


\section{Environmental Values}

As per-capita income increases, so too will the demand for the services of natural environments. Empirical evidence substantiates this claim for some features of the environment (e.g. air quality, water qualıty, and outdoor recreation), and the positive relationship between income and environmental demands is probably more broadly applicable as well.

At the same time, timber production will reduce the supply of these same services. Because local and global environmental services lie largely outside formal markets, it is a simple truism that they are systematically undervalued in forest consumption and production decisions. As a consequence, market-based patterns of forest use are unlikely to reflect the true social values of these inputs and outputs. This mismatch between the social valuation of natural environments and their production in market-based decisions will widen over time. Once the gulf is sufficiently large to overcome transactions costs. institutions will emerge to place values on these services. They may actually be traded in markets. or they may be protected through direct governmental regulation or through elaborate and costly mechanisms of public involvement in forest decision making. The cost of environmental inputs will rise as part of the endogenous economic dynamics of the forest sector. Total factor productivity will decline as these previously free inputs carry positive costs.

\section{Traditional Policy Responses}

The endogenous dynamics of the forest sector produce several kinds of social stress. Capital-labour substitution creates unemployment problems, particularly in the rural areas where most processing facilities are found. In remote, rural communities the forest sector typically is closely interlinked with the rest of the economy. This tight coupling amplifies these job reductions to produce higher levels of community instability than urban regions suffer (Berck et al. 1992). Unemployment places downward pressure on wages and material standards of living.

Where institutional factors make wage-rate adjustments sticky, capital-labour substitution continues to occur beyond the socially optimal level. As more and more capital is used in the sector, the return on incremental capital falls. Firms look elsewhere to invest the cashflow generated by the domestic forest sector. Total factor productivity declines, and the standard of living stagnates still further.

These social problems press politicians for solutions. Some of the traditional solutions have pernicious side effects or are doomed to failure in a competitive market place.

For example, Indonesia recently banned the export of logs in the hopes of offsetting the decline in employment which is part of the economic dynamics of the sector. This policy increased the supply of logs in the domestic market and depressed their price. Lower log prices created an incentive to back-substitute timber for capital. This reversal of the development process will create an internationally inefficient processing industry and a loss of value to society. The result will be a chronically low level of development for the sector. Vincent (1986, 1992) demonstrated these problems in the Malaysian forest sector, and showed that log-export restrictions cost that country $\$ 6,100 / \mathrm{yr}$ in true economic valueadded for each $\$ 2.200 / \mathrm{yr}$ job created in the processing sector.
Adding value within the forest sector is another popular policy response. Specifically, countries seek to deepen domestic processing and export the finished products. For example, the Russian Far East is seeking to substitute lumber and panel exports for log exports, and, still better, furniture exports for lumber and panel exports. Similarly, they are seeking to substitute pulp and paper exports of wood chips. Through these activities they can convert rouble-denominated labour into hard currency (Cardellichio, Binkley and Zausaev 1990).

Unfortunately, the competition for value-added exports is fierce. If every country applies this policy, as they seem to, then the profitability of doing so will diminish. Where does the country's competitive advantage lie? If trees are available in second-growth forests and technology is universal, then the comparative advantage will generally flow to those countries with low-cost labor (witness the success of Taiwan's furniture industry). Said another way, following a value-added policy with universally available technology condemns the forest sector to low wages, and a secondary status in labour markets. This is clearly not a socially or politically acceptable outcome in Canada.

As a consequence of these problems in Canada, our politicians now express an unusual interest in "productivity." Porter (1990) puts the issue well:

Productivity is the prime determinant in the long run of a nation's standard of living, for it is the root cause of national per-capita income.

In his study of Canada, Porter (1991) goes on to say:

Canada's economy, and especially its export economy, is heavily based on natural resources. Some argue that resource industries are inherently less desirable than manufacturing or "high-tech" industries. This logic is flawed. There is nothing inherently undesirable about resource-based industries, provided they support high levels of productivity and productivity growth. Such industries can make a country wealthy if its resource position is highly favourable, as has been the case for Canada during most of its history. If resource-based industries continually upgrade their sophistication through improvements in their processes and products, competitive positions can be sustained and productivity growth insured. [Emphasis added]

Productivity growth can occur through reductions in the total cost of inputs or through increases in the value of outputs. There is endogenous upward pressure on raw material costs, and reducing wage rates is not socially attractive. As a consequence, the only acceptable, sustainable answers seem to lie in more efficient production of more valuable products. Research and development is perhaps the only way to achieve these ends.

\section{The Political Necessity}

An expanded forestry research program is also necessary to create a more stable policy environment in which the forest products industry can survive and prosper.

The current turmoil in forest policy arises, in part, as an inevitable result of scientific epistemology. No scientific hypothesis can ever be proved correct. Rather, science is the process of proving incorrect hypotheses to be false. The successive falsification of hypotheses narrows the area of 
scientific uncertainty until finally we collectively claim to "know" something to be true.

Too little scientific effort has been applied to forestry problems. As a consequence, too many hypotheses remain unfalsified. These possibly incorrect but untested hypotheses possess a measure of scientific credibility among the public. In the absence of scientific evidence to the contrary, no credible scientific expert can refute such an hypothesis. An interest group can seize a plausible but untested hypothesis which happens to fit its political agenda and claim, with complete and unassailable justification, that "there is no scientific evidence to the contrary",

Policy debates become confused as these unfalsified but untested hypotheses compete for the limited attention of policy makers. The policy environment is unstable because the latitude for choice is wide and the objective capacity to screen alternatives is limited.

Three questions that arise in current policy debates illustrate the nature of the problem:

(i) Are current forest management systems sustainable in the long run? In North America there is little if any direct, empirical evidence that current management practices do not result in reductions in yield after several rotations. Indeed only a very small area of the forest land in the United States or Canada has been managed over more than a single rotation. Our arguments about long-term sustainability therefore rest on important but indirect measures such as the status and flow of nutrients. Compare this with the situation in central Europe where some forests have been managed and observed for 400 years. The development of process-based knowledge of forest growth and ecosystem function is critical to better forest policy. The need grows ever larger as we add new concerns such as the response of forests to climate change, or the effects of increased UV-B radiation on forest ecosystems.

(ii) What are the ecological impacts of forest management practices such as clearcutting? Clearcutting as a method to regenerate forests is commonly justified on its resemblance to the natural processes of wildfire which lead to the renewal of large, even-aged areas of nearly pure coniferous forests. But what are the differences in fireregenerated stands and clear cuts in terms of understory vegetation, communities of soil microorganisms and the processes of nutrient cycling? The list of concerns could go on, and indeed will grow longer as the public debate inevitably becomes more sophisticated.

(iii) What are the biodiversity implications of alternative forest management regimes? Even posing this question raises a host of subsidiary questions: of the many methods available, how should we measure biodiversity? how much biodiversity do we, as a society, want? In the future these questions will take on added importance as we realize, as some do now, the active need to manage natural areas and preserves. It is increasingly evident that the unique biota we cherish in parks is poorly served by a policy consisting of simple land preservation and nothing more.

In short, past forestry research has wisely spent $20 \%$ of the necessary resources to get $80 \%$ of the answers. As a consequence, our research expenditures have produced good returns on the money spent. But now the public debate about forest practices and forest policies demands that we find the other $20 \%$ of the answers.

\section{The Research Need}

We face a changing definition of what society wants from the forest sector. At one time, it was enough to produce land for agriculture, high-paying jobs, a basic industrial material and the capital needed for economic development and societal welfare. Now society demands all of this and more. Technology is the only known method of getting more from less. Current levels of research are not providing the needed technology fast enough to keep pace with society's increased demands.

This state of affairs is not unique to British Columbia or to Canada. The National Academy of Sciences of the United States (1990) recently concluded

Although concern about and interest in the global role and rate of forests are currently great. the existing knowledge about forests is inadequate to develop sound forest-management policies. Current knowledge and patterns of research will not result in sufficiently accurate predictions of the consequences of harmful influences on forest. including forest-management practices that lack a sound basis in biological knowledge. This deficiency will reduce our ability to maintain or enhance forest productivity. recreation and conservation, as well as our ability to ameliorate or adapt to changes in the global environments.

In short, the problem is to develop technology that will increase productivity from a shrinking land base, and that will confer sustained competitive advantage for our forest sector.

Hyde et al. (1989, see also Seldon and Hyde 1991) studied examples of both forestry and forest products research in the United States. They found the latter to produce very high positive net economic benefits. However, most of the benefit accrued to consumers in the form of lower prices. Clearly a similar research strategy would serve a net producer such as Canada very poorly. Creating sustainable competitive advantage through technology will be more difficult here.

Our research program needs to be directed strategically to offset the long-run economic dynamics identified in this paper. Three guidelines seem sensible:

(i) Develop and apply socially acceptable technologies to increase production on a smaller land base. For example. my colleague Professor D. Lester estimates that the gain in volume from first generation seed orchards ranges from 2.0-8.4\% for coastal Douglas fir, to $18.4 \%$ for interior Douglas fir, to $4.4 \%-24.6 \%$ for interior spruces. Site amendments are known to have even larger effects. We may be able to manage soil microorganisms to increase growth. Managed stands can yield two to five times the production of natural stands on the same site, and even these high yields are no more than half the maximum yields theoretically possible (Farnum et al. 1983). The over-arching need is to develop the capacity to design, from first principles, high performance forest ecosystems and thereby eliminate the current cut-and-try methodology.

(ii) Lead in the development of technology for secondary processing. If technology is universal, competitive advantage in the forest sector derives mainly from low wage rates. No tenable first-world policy condemns workers to thirdworld wages. Yet if specialized technological development 
does not progress simultaneously with an emphasis on process deepening, those employed in the secondary sector can never have wages significantly higher than those in competing nations. A research policy that relies on broadly-based equipment manufacturers cannot produce the needed technological leverage.

(iii) Specialize in products for which there are few substitutes. A truism of industrial strategy calls for specialization in products with inelastic demand. Such products can be created either by patent-protected technologies, or by taking advantage of specialized factors of production (e.g. western red cedar). By definition, universally applicable, open research and development can never produce strategically advantageous products. Developing such products requires locally-based $R \& D$.

The kind of strategic research program envisaged here requires the usual economic inputs - land, labor, time and capital. Concerning land, British Columbia needs a system of permanent research forests (Binkley 1992). These should cover all of the major biogeoclimatic zones. The watershed should be the basic unit of analysis, with due attention to landscape-scale phenomenon. There should be enough of these units in each zone to permit a reasonable degree of replication in experiments. Some of the areas should have no constraints on possible manipulations, while some could remain in their "natural" state as controls. Tenure as research forests should be permanent. British Columbia's present system of Ecological Reserves serves some, but not all, of these needs.

Concerning labor, the current production of forestry Ph.D.s in Canadian universities is inadequate to support the needed research program. Carrow (1990) estimates that there are $166 \mathrm{Ph} . \mathrm{D}$. students currently enrolled in the six Canadian forestry schools that grant doctoral degrees. Assuming an average of six years to complete a Ph.D., the current annual production is about 28 . Slightly over half of all graduate students in Canadian forestry schools are foreign, probably with some obligation to return to their home country. Taken together, these facts suggest that the current production rate of Canadian forest scientists lies in the range of 10-20/year for the next five years. Given the faculty turnover expected in the next decade, this level of production is unlikely to fill replacement demand in universities, let alone expanded research efforts. This situation can be partially rectified by bringing more kinds of scientists - from botany, microbiology, economics - to the problems of forestry research. But if scientific personnel are appropriately recruited from these disciplines, they will need some time in postdoctoral or similar training to gain the detailed understanding of forestry problems that is necessary for effective application of their disciplinary skills.

Concerning time, we need to start now long-term research projects related to the long-term sustainability of forest management systems. Located on the system of research forests described above, these experiments would provide a continuing basis for answering the difficult questions posed by an increasingly skeptical public.

Long-term research is frequently criticized as providing results in a time frame that is not useful to current policy problems. But think back to 1965 . Most of the questions raised now can be found, perhaps worded differently, in the record of the debates from that era. Imagine if we had started a systematic program of long-term forestry research then.
Concerning capital, at the outset of this paper I outlined the magnitude of the funding problem. How can these funds be raised? Once raised, how should they be disbursed?

Raising the funds from a direct tax on timber harvests is probably not feasible. Harvest levels in British Columbia recently peaked at about 89 million cubic metres annually. At this level of harvests (which may never again be attained), a tax on stumpage of about $\$ 2.70 /$ cubic metre would be required to raise the full $\$ 240$ million for research. Stumpage fees averaged \$5.89/cubic metre in 1987/88 (Province of British Columbia, 1988; Table D-3), so adding a "research tax" of the requisite size would significantly increase industry costs and reduce international competitiveness. Other fiscal mechanisms must be designed to raise the necessary funds.

The methods used to disburse these strategically targeted research funds should insure that the very best scientific resources work on our problems, and should help build over the longer term an excellent, sustainable research capacity in Canada. Open competitions will help achieve these objectives. Scientists from any legitimate research institution should be eligible for research support. This would include governmental research laboratories, industrial facilities, private research groups and all departments of colleges and universities. At the same time, care must be taken that highly qualified young researchers are adequately supported, and that the competitions are not so finely circumscribed that they preclude the kind of long-term, collaborative, interdisciplinary research so desparately needed to solve our forestry problems. The point is to attract the very best scientific talent to solving the strategic problems of the forest sector, and to build the kind of indigenous capacity in Canada that will create and secure over the long run sustainable competitive advantage.

\section{Conclusions}

The future of the forest sector in British Columbia and probably elsewhere in Canada depends on its transformation from being a resource-based sector to becoming a knowledge-based one. The now well-understood economic dynamics associated with the transition between old- and second-growth forests produce severe economic and social dislocations, particularly in such places as British Columbia where the forest sector comprises a large part of the overall economy.

One policy approach would write off the sector, planning for its demise in both absolute and relative terms but using the economic rents it generates to finance investment in other economic activities. This approach easily ignores both the costs of the transition, and the difficulties of creating new industries where they never existed before. But more importantly, it ignores the long-term, sustainable competitive advantage that can accrue from a knowledge-based forest sector.

Creating this alternative vision for the forest sector will require a substantially larger investment in research and development than we currently make. The investment should include more scientific personnel and more land devoted to the scientific study of forestry.

But increased investment in research alone will not suffice. Most importantly, we need a competitively-targeted R\&D strategy. This strategy should support the unique Canadian circumstances as an internationally significant producer. 
It should recognize our factor costs: wage rates and the standard of living are high, timber is no longer cheap, environmental concerns are advanced and the alternative uses of forest land for parks and preserves make extensive forms of industrial timber production increasingly costly and socially unacceptable. By thoughtfully applying more knowledge, we can offset the economic decline that is built into dynamics of a forest sector based on old-growth timber, and sustain the forest's contributions to Canada's economy, society and culture.

\section{References}

Berck, P., D. Burton, G. Goldman and J. Geoghegan. 1992. Instability in forestry and forestry communities. Chapter 14 In Emerging issues in forest policy. P.N. Nemetz (ed.) UBC Press: Vancouver, BC.

Binkley, C.S. 1992. The need for a system of experimental forests in British Columbia. Presented at the Experimental Forests Workshop, 28-29 April, 1992, Victoria, B.C. 8 p.

Binkley, C.S. and S.B. Watts. 1992. The status of forestry research in British Columbia. For. Chron. 68: 730-735.

Binkley, C.S. and J.R. Vincent. 1988. Timber prices in the US South: past trends and outlook for the future. S.J. Appl. Forestry. 12: $15-18$

Cardellichio, P.A., C.S. Binkley and V.K. Zausaev. 1990. Potential expansion of Soviet Far East log exports to the Pacific Rim. J. For. 88(6): 12-17.

Carrow, R. 1990. Forestry research in the university: motivation and achieving excellence. Paper presented at the 1990 Canadian Institute of Foresters meeting, 22 August.

Clawson, M. 1979. Forests in the long sweep of American history. Science 204: 1168-1174.

Evenson, R.E., P.E. Waggoner, and V.W. Ruttan. 1979. Economic benefits from research: an example from agriculture. Science 205: 1101-1107.

Farnum, R., R. Timmis and J.L. Kulp. 1983. The biotechnology of forest yield. Science 219: 694-702.

Hyde, W.F., D.H. Newman and B.J. Seldon. 1989. The economic returns to forestry research. Forest Economics and Policy Analysis Project Working Paper 134.

Lester, D. n.d. Predicted genetic gains from first-generation seed orchards of major conifers of British Columbia. Report to the Coastal and Interior Tree Improvement Councils: UBC, Vancouver, BC.
Lyon, K.S. 1981. Mining of the forest and the time path of the price of timber. J. Env. Econ. Mgmt. 8: 330-344.

National Academy of Sciences. 1990. Forestry research: A mandate for change. National Research Council: Washington. DC.

Nixon, R. 1991. Comparative data charts explain forest management policies. Forest Planning Canada. 7: 32-45

Porter, M. 1990. The competitive advantage of nations. The Free Press: New York.

Porter, M. 1991. Canada at the crossroads: The reality of a new competitive environment. A study prepared for the Business Council on National Issues and the Government of Canada. Harvard Business School and Monitor Company.

Province of British Columbia. 1988. Annual report. 1987-1988. Ministry of Forests and Lands: Victoria, BC.

Science Council of British Columbia. 1989. Forestry research and development in British Columbia. Prepared by the Forestry Planning Committee. October.

Sedjo, R. 1990. The nation's forest resources. Resources for the Future Discussion Paper ENR90-07.

Sedjo, R. and K.S. Lyon. 1983. Long-term forest resources trade. global timber supply and intertemporal comparative advantage. Amer. J. Ag. Econ. 65: 1010-1016

Sedjo, R.A. and K.S. Lyon. 1990. The long-term adequacy of world timber supply. Johns Hopkins University Press. Washington. DC.

Seldon, B.J. and W.F. Hyde. 1991. An evaluation of public research in three forest products industries. For. Sci. Vol. 37: 669-687.

Vincent, J.R. 1986. Growth of forest products industry in Malaysia: 1961-1985. Malaysian Forester 49: 223-240.

Vincent, J.R. 1992. The tropical timber trade and sustainable development. Science 256: 1651-1655.

Vincent, J.R. and C.S. Binkley. 1991. Forest-based industrialization: A dynamic perspective. Harvard Institute for International Development. Devel. Dis. Paper 389. Harvard University, Cambridge, MA.

Vincent, J.R. and C.S. Binkley. 1992. Forest-based industrialization: a dynamic perspective. Ch. 6. In: N.P. Sharma (ed.) Managing the world's forests. Kendall/Hunt: Dubuque. IA, for the World Bank.

Vincent, J.R. and M. Newmark. 1992. Deforestation, agricultural expansion and capital accumulation in an open economy. Draft ms. Harvard Institute for International Development. Harvard University, Cambridge, MA.

\section{Change of Address}

Date Section

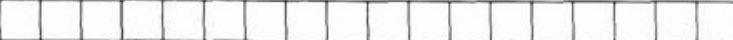

Surname first - no titles

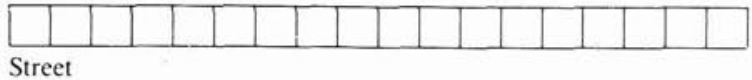

\begin{tabular}{|l|l|l|l|l|l|l|l|l|l|l|l|l|l|l|l|l|}
\hline & & & & & & & & & & & & & & & & \\
\hline
\end{tabular}

City and Province

\begin{tabular}{|l|l|}
\hline & \\
Postal Code
\end{tabular}

\section{Changement d'adresse}

Date Section

Prénom en avant - pas de titres

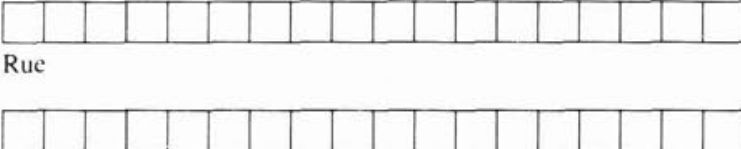

Ville et Province

Code Postale 